\title{
Contents, Vol. 71, Supplement 1, 1997
}

\section{Biology of the Neonate}

\section{Preface}

Curstedt, T. (Stockholm); Halliday, H.L. (Belfast); Robertson, B. (Stockholm); Saugstad, O.D. (Oslo); Speer, C.P. (Tubingen); Svenningsen, N.W. (Lund)

1 Surfactant Therapy in the USA: Trials and Current Routines

Soil, R.F. (Burlington, Vt.)

8 Clinical Trials of Surfactant Replacement in Europe

Halliday, H.L. (Belfast)

13 Ventilation Patterns, Surfactant and Lung Injury

Jonson, B. (Lund)

18 Circulatory Effects of Surfactant Therapy

Moen, A. (Oslo)

23 Free Oxygen Radicals and Surfactant

Bracci, R. (Siena)

28 From Bubbles to Babies: The Evolution of Surfactant Replacement Therapy

Enhorning, G. (Buffalo, N.Y.)

32 Resuscitation Strategy and Surfactant Therapy

Werner, O.; Björklund, L.J. (Lund)

35 Experimental Models of Bronchopulmonary Dysplasia

Coalson, J.J. (San Antonio, Tex.)

39 Clinical Aspects of Nitric Oxide and Surfactant Replacement

Frostell, C.G. (Danderyd)

44 Molecular Interactions between Nitric Oxide and Lung Surfactant

Hallman, M. (Irvine, Calif./Oulu)

49 Protein Analogues in Artificial Surfactants

Johansson, J. (Stockholm)

53 Abstracts 69 Author Index

\section{KAKGEK}

E-Mail karger@,karger.ch Fax+41 613061234 http://www.karger.ch

(C) 1997 S. KargerAG, Basel

The list of contents is available at: http://www.karger.ch/journals/bon/boncont.htm

III

Biology of the Neonate

Tore Curstedt Preface

Henry L. Halliday Bengt Robertson Ola Didrik Saugstad Christian P. Speer Nils W.

Svenningsen

Surfactant therapy is today part of the routine clinical management of preterm babies with respiratory problems due to lung immaturity, and there is accumulating evidence from both animal models and clinical studies that this treatment may also improve lung function in other 
neonatal respiratory disorders such as meconium aspiration syndrome or pneumonia. In the 1980s and 1990s several trials documenting the beneficial effects of surfactant therapy for prevention and treatment of neonatal respiratory distress syndrome were organized by the 'Collaborative European Multicenter Study Group', a network of neonatologists and basic scientists with a common interest in the biochemistry, biophysics, physiology, and clinical importance of the pulmonary surfactant system. This group has held annual meetings since 1986, and the articles and abstracts published on the following pages represent the proceedings of the '12th International Workshop on Surfactant Replacement', which took place in Stockholm from May 29 to June 1, 1997. As can be seen from the list of speakers participating in the meeting and the variety of topics, the network is no longer limited to Europe, and the research projects conducted by members of the group are not restricted to a single commercial product. The issues addressed include new clinical targets for surfactant therapy, comparative clinical trials of natural and synthetic surfactants, new patho-physiological aspects of surfactant deficiency and inactivation, roles of inflammatory mediators and free oxygen radicals in the patho-genesis of bronchopulmonary dysplasia, effect of surfactant on bacterial proliferation in experimental neonatal pneumonia, molecular interactions between nitric oxide and surfactant, and development of new artificial surfactants based on synthetic analogues of the native hydrophobic surfactant polypeptides. Although some leading pediatricians may claim the opposite, surfactant is still a hot topic, which will keep investigators all over the world busy for many more years. As always, this Workshop, while answering some questions, has posed many more which will need careful basic investigation and clinical trials to answer properly. We are happy that the Editor of Biology of the Neonate, Prof. Jean Pierre Relier, has given us the opportunity to make this update on surfactant research available to a wide audience.

KAR.GER. (C) 1997 S.KargerAG, Basel

E-Mail karger@karger.ch Fax + 41613061234 http://www. karger. ch 